\title{
The performance of nursing students in a tele-health service during the COVID-19 pandemic
}

\author{
Atuação de estudantes de enfermagem em um serviço de \\ telessaúde durante a pandemia COVID-19 \\ Desempeño de estudiantes de enfermería en un servicio de \\ tele-salud durante la pandemia COVID-19
}

\author{
Luana Daiane Guimarães Lima ${ }^{a}$ \\ Jamila Geri Tomaschewski-Barlem ${ }^{a}$ \\ Gabriela do Rosário Paloski ${ }^{\mathrm{a}}$ \\ Edison Luiz Devos Barlem ${ }^{a}$ \\ Laurelize Pereira Rocha ${ }^{a}$ \\ Janaína Sena Castanheira ${ }^{a}$
}

\section{How to cite this article:} Lima LDG, Tomaschewski-Barlem JG, Paloski GR, Barlem ELD, Rocha LP, Castanheira JS. The performance of nursing students in a tele-health service during the COVID-19 pandemic. Rev Gaúcha Enferm. 2021;42:e20200483. doi: https://doi. org/10.1590/1983-1447.2021.20200483
Universidade Federal do Rio Grande (FURG), Escola de Enfermagem. Rio Grande, Rio Grande do Sul, Brazil.

\section{ABSTRACT}

Objective: To identify the experiences of nursing students working in a telehealth service to fight the COVID-19.

Method: Qualitative, exploratory, and descriptive study, addressing 31 undergraduate nursing students at a Federal University located in the extreme south of Brazil. Data were collected in October 2020 using an online questionnaire. Textual discourse analysis was used to interpret data.

Results: The students identified facilities, weaknesses, and potentialities of a telehealth service, verifying that it is a strategy that favors the development of skills and competencies during the training of students and to fight the COVID-19 pandemic

Conclusion: The results reveal the students' experiences in a telehealth service designed to fight the COVID-19, showing the importance of including this service in the routine of healthcare services.

Keywords: Nursing. Coronavirus infections. Telemedicine.

\section{RESUMO}

Objetivo: Conhecer as experiências de estudantes de enfermagem na atuação em um serviço de telessaúde para enfrentamento da COVID-19.

Método: Estudo qualitativo, exploratório e descritivo, realizado com 31 estudantes de graduação em enfermagem de uma Universidade Federal localizada no extremo Sul do Brasil. Os dados foram coletados em outubro de 2020, por meio de um questionário online, no qual procedeu-se a análise textual discursiva.

Resultados: Foram identificadas as facilidades, fragilidades e potencialidades na atuação de estudantes de enfermagem em um serviço de telessaúde, constatando-se que o mesmo constitui-se de uma estratégia favorável tanto para o desenvolvimento de habilidades e competências na formação dos estudantes quanto para o enfrentamento da pandemia COVID-19.

Conclusão: Constatou-se que o estudo conseguiu identificar as experiências dos estudantes em relação à atuação em um serviço de telessaúde no enfrentamento da COVID-19, demonstrando a importância de incluir esse serviço no cotidiano do cuidado em saúde. Palavras-chave: Enfermagem. Infecções por coronavírus. Telemedicina.

\section{RESUMEN}

Objetivo: Conocer las experiencias de estudiantes de enfermería que trabajan en un servicio de telesalud para enfrentar el COVID-19. Método: Estudio cualitativo, exploratorio y descriptivo, realizado con 31 estudiantes de pregrado en enfermería de una Universidad Federal ubicada en el extremo sur de Brasil. Los datos fueron recolectados en octubre de 2020, a través de un cuestionario en línea, en el que se realizó un análisis textual discursivo.

Resultados: Se identificaron las facilidades, debilidades y potencialidades en el desempeño de los estudiantes de enfermería en un servicio de telesalud, demostrando que constituye una estrategia favorable tanto para el desarrollo de habilidades y competencias en la educación de los estudiantes como para el afrontamiento de la pandemia COVID-19.

Conclusión: Se encontró que el estudio logró identificar las experiencias de los estudiantes en relación al trabajo en un servicio de telesalud en el afrontamiento de COVID-19, demostrando la importancia de incluir este servicio en la atención diaria de la salud. Palabras clave: Enfermería. Infecciones por coronavirus. Telemedicina. 


\section{口INTRODUCTION}

As the World Health Organization (WHO) called, the novel Coronavirus (SARS-CoV-2) emerged in December 2019, resulting in an outbreak of pneumonia in Wuhan, China. Due to the virus' high transmissibility, on January $30^{\text {th }}, 2020$, WHO declared that the new coronavirus outbreak constituted a Public Health Emergency of International Concern $^{(1)}$.

The most common symptoms of the coronavirus 2019 (COVID-19) include fever, fatigue, dry cough, body aches, runny nose, nasal congestion, headache, sore throat, diarrhea, loss of taste and smell, skin rashes, and the discoloration of fingers and/or toes may also occur. These symptoms are usually mild and start gradually. Some people may not present any symptoms even if infected, while others may become seriously ill and die(2).

Regarding the prevention and control of the disease, different approaches have been adopted to slow down its spread and decrease the burden on the health system. The interventions include increased testing for diagnostic support, clinical management, rapid isolation of suspected and confirmed cases and contacts, and primarily restricting mobility ${ }^{(3)}$.

Note that the pandemic has caused significant changes in health care processes, demanding health systems to reorganize and screen patients more efficiently while concomitantly decreasing the exposure of health workers, the community, and the patients to the virus. Hence, telehealth services became an important strategy to fight the pandemic by preventing patients from traveling unnecessarily and decreasing the time necessary to provide care and reach diagnoses ${ }^{(4)}$.

According to the WHO, telehealth can be defined as remote health services provided by health professionals in situations when distance is a critical factor, using Information and Communication Technologies (ICTs) to exchange valid information to diagnose, treat and prevent diseases, support research and assessments, provide continuing education to health workers, and promote the health of individuals and communities ${ }^{(5)}$.

The adoption of telehealth services to provide remote clinical care has increased significantly in recent years and has great potential to be used in the context of public health emergencies. Hence, the use of these services is not recent in the international context, considering disasters and health emergencies, and the fact that the United States of America has more than 50 health systems with telehealth programs providing remote medical assistance to patients and referring moderate and severe patients to nursing screening systems ${ }^{(6)}$.

In Brazil, telehealth services within the public health system were implemented in 2003 through the BH-Telessaúde [BH-Telehealth] project, with an emphasis on Primary Healthcare (PHC); and the Homem Virtual [Virtual Man] project at the University of São Paulo (USP), which became a reference to support the development of the Projeto Telessaúde Brasil [Telehealth Brazil project] promoted by the Ministry of Health ${ }^{(7-8)}$.

In the context of a public health emergency of international concern due to the COVID-19, telehealth services were regulated by the Federal Government and Ministry of Health together with the Federal Council of Medicine (CFM) and Federal Council of Nursing (COFEN) to implement strategies to fight the pandemic ${ }^{(9)}$.

Teleconsultations in the nursing field are regulated by Resolution COFEN No. 634/2020 and concern consultations, referrals, and orientation provided using information and communication technologies, such as audiovisual resources and databases that enable nurses to contact patients remotely in real-time. In addition, similarly to face-to-face consultations, teleconsultations must comply with the rules established by the Code of Ethics of Nursing Professionals, which determine a set of aspects concerning the integrity of patients and the recording of patients' information ${ }^{(10)}$.

However, even though the universities' curriculum guidelines and Pedagogical Projects are designed to train future nurses to work in the different settings that compose the health system, the academic training of nurses does not seem to include experiences with telehealth services as a field of practice within the profession. Therefore, knowledge regarding the context of the use of telehealth services is necessary to consolidate effective services. For this reason, the experiences, satisfaction, and needs of those using these services need to be investigated.

Therefore, this study's guiding question was: What are the experiences of nursing students working in a telehealth service to fight the COVID-19? The objective was to identify the experiences of nursing students working in a telehealth service to fight the COVID-19.

This study is very opportune and relevant because it will portray the experiences of students from the undergraduate nursing program of a Federal University located in Southern Brazil. These students will be the precursors and/or multipliers of the knowledge acquired in the service, which will encourage discussions regarding the pedagogical needs that permeate the training of nurses to work in telehealth services. 


\section{METHODS}

This is a qualitative, exploratory-descriptive study, which enables understanding phenomena based on a detailed analysis and interpretation of textual elements collected from the participants' written reports in response to this study's questionnaire ${ }^{(11)}$.

The study setting was a telehealth service designed to fight the COVID-19. The service was developed by a Federal University located in southern Brazil in partnership with the Health Department located in a city with approximately 211,965 inhabitants, at $316 \mathrm{Km}$ from Porto Alegre, capital of Rio Grande do Sul (RS). This service is intended to promote quality care, providing guidance, clarification of doubts, and medical and nursing care, and is divided into Tele-screening and Telehealth guidance.

At the time of the data collection, the numbers of cases and deaths in the city due to COVID-19 were 4,641 and 132, respectively, whereas the capital of RS had 44,589 confirmed cases and 1,277 deaths ${ }^{(12)}$.

The study's participants were 31 nursing students who performed their supervised training in this service. Therefore, the following inclusion criteria were adopted: students regularly enrolled in the Nursing Undergraduate Program performing their supervised curricular training in the telehealth service previously mentioned to fight the COVID-19. The exclusion criterion was not having access to the Internet to complete the data collection instrument.

Data were collected in October 2020 using an online form (Google Forms) addressing the students' experiences regarding the object of study. The questionnaire contained questions addressing the participants' characteristics such as age, sex, and how long they worked in the service. Additionally, the form included open-ended questions addressing the nursing students' experiences regarding their work in the telehealth service during the COVID-19 pandemic, for instance: What are the main difficulties and facilities experiencing during your work? Additionally, the students were asked about the clinical assessment of patients, decision-making, the use of technology, and the relationship established with the multi-professional team. All the participants signed a free and informed consent form.

Data were submitted to Textual Discourse Analysis to obtain a new understanding of the phenomenon under study through a self-organized process composed of three stages: unitization, categorization, and communication ${ }^{(11)}$.

The responses were read in detail in the unitization stage until they formed units of meaning; i.e., units of meaning emerged from deconstructing the text, establishing the different meanings in detail, however, never reaching a final or absolute limit. In the categorization stage, relationships were established between the units, grouping similar elements and combining and classifying them into categories (Chart 1). Finally, in the communication stage, new understandings emerged regarding the phenomenon under study ${ }^{(11)}$.

Ethical guidelines were complied with, and the study was submitted and approved by the Ethical Review Board under CAEE No. 38605920.5.0000.5324. The participants' reports were coded in the presentation of results so that the letter "S", which stands for Students, was associated with a number corresponding to the order in which the questionnaires were completed.

\section{RESULTS AND DISCUSSION}

Thirty-one out of 38 students who worked 20 hours/week for three months on average in the telehealth service to fight the COVID-19 pandemic participated in the study. None of the students had had any experience with the telehealth service during the nursing undergraduate program before the COVID-19 pandemic.

The participants'age ranged from 21 to 49, whereas most participants were women: 30 women and one man. The students were attending the last year of the undergraduate nursing program at a Federal University located in southern Brazil, and their tasks included clarifying doubts, tele-screening, and referring patients suspected or confirmed of COVID-19.

The data analysis process resulted in two categories: facilities, weaknesses, and potentialities of the work in telehealth services; and knowledge, skills, and competencies developed in the telehealth service.

\section{Facilities, weaknesses, and potentialities of the work in telehealth services}

This category presents the elements concerning facilities, weaknesses, and potentialities the students envisioned in work performed in the telehealth service. Among the facilities, the students mentioned using protocols as a strategy that favors the assessment of cases. Protocols standardize assistance and guidance, avoiding divergent conduct. Although different students and professionals work in the service, as the following excerpt shows, protocols ensure uniform service and consonant decision-making.

The main facility refers to the use of clear protocols when assessing the cases, such as classifying and later making the correct referral. The use of clear protocols to guide assessment, classification, referral, and guidance made the experience of working in the service satisfactory. (S19) 


\begin{tabular}{|c|c|}
\hline CATEGORY & UNITS OF MEANING \\
\hline \multirow{9}{*}{$\begin{array}{l}\text { Facilities, weaknesses, and potentialities in } \\
\text { work performed in the telehealth service }\end{array}$} & The use of protocols \\
\hline & Access to information \\
\hline & Technical support \\
\hline & Telephone system \\
\hline & Platform management \\
\hline & Fragmentation of health services \\
\hline & Impossibility of performing physical assessments \\
\hline & Importance of the service \\
\hline & Expansion of the service \\
\hline \multirow{5}{*}{$\begin{array}{l}\text { Knowledge, skills, and competencies } \\
\text { developed in the telehealth service }\end{array}$} & Clinical reasoning \\
\hline & Use of technology \\
\hline & Communication \\
\hline & Relationship with the multi-professional team \\
\hline & Decision making \\
\hline
\end{tabular}

Chart 1 - Units of meanings and categories of analysis. Rio Grande, Rio Grande do Sul, Brazil, 2021

Source: Study's data, 2021.

Decision-making was guided by the protocols, which makes you more self-assured. (S31)

The students' conceptions regarding the use of protocols in health services are consonant with the literature, showing that protocols facilitate clinical assessment, making it safer and more effective, both in face-to-face and remote consultations. Therefore, the development of protocols optimizes the telehealth service and care provided to users ${ }^{(13)}$. Additionally, the use of these protocols during the COVID-19 pandemic standardizes care, directing clinical prescriptions and supporting decision-making, avoiding unnecessary referrals, or exposing patients to health risks. Therefore, it prevents overloading face-to-face health services because, depending on the patient's symptomatology, patients may remain sheltered at home or be referred to a specialized health service ${ }^{(14)}$.
Access to information was also reported as a factor that facilitates the work in the service because the remote work and free access to the Internet enabled students to seek clarification, searching the official websites of the Ministry of Health and the WHO, which constantly provided updated information regarding the COVID-19.

I believe that the main facility is that it's a virtual home office job. I was able to reconcile everything in myschedule, had plenty of time to dedicate myself to the service, and had easy access to information whenever I needed to clarify doubts and answer the patients. (S21)

One study conducted in Pernambuco, Brazil, corroborates the students' reports concerning access to information. The study previously mentioned reports that access to the information within the context of telehealth 
services is facilitated by virtual technologies widely used during consultations such as the virtual service platform, WhatsApp, and Google Scholar, which facilitate the search for information and contact with other workers, nurses or physicians to discuss cases. Furthermore, the same study argues that information and communication technologies are responsible for disseminating information, especially within the COVID-19 pandemic, and educational data regarding preventive measures to avoid the spread of the virus, constantly updating data regarding suspected and confirmed cases of COVID-19, and reporting the number of hospitalizations in ICUs and deaths daily. One of the agencies responsible for updating this information is the Ministry of Health, which at the beginning of the pandemic provided updated information through the COVID-19 electronic panel(10-11) but, over time, started restricting information ${ }^{(14-15)}$.

Additionally, the students also reported that the technical support provided by other professionals working in the service was a factor that facilitated their practice, making them feel more self-assured and calm to perform consultations.

The system was easy to deal with, had all kinds of information, and you just had to follow it and provide the answers. The supervisors and the professor were always willing to help in case of doubts. Knowing that other professionals were working in the service facilitated my job a lot. (S31)

As mentioned earlier, the technical support provided by other professionals was highlighted as a factor that facilitated the service. This support was provided by the nurses supervising the students and nurse professors from the undergraduate nursing program, in addition to a multi-professional team composed of community health agents, nurses, and physicians working in the city's primary healthcare network, with whom the students worked as a team, making connections with their technical and scientific knowledge whenever discussing and referring cases.

Knowledge is essential to fight the COVID-19 so that in addition to knowing the infection and the patients' clinical conditions, the students needed to have the ability to deal with psychological issues, considering that many patients were anxious about the pandemic ${ }^{(16)}$. Therefore, the students' work encompassed guidance regarding health issues, information involving aspects related to the infection, such as transmission and testing, and the clinical assessment of patients to make adequate referrals.

In this sense, it is essential to note that telehealth is a service that integrates, supports, and strengths teaching and encourages active participation and the exchange of knowledge between students and health workers. Additionally, it enables and promotes discussion of cases and increases the opportunities and means to conduct research and assessment of health practices ${ }^{(17-18)}$.

Regarding weaknesses, the students reported difficulties with the telephone system, listing several unforeseen events such as landline dropped calls and interrupted calls, so that the users needed to be informed of the possibility of having to return the call. In addition, difficulties in managing the platform were also reported, such as when the students were adapting to the service or by the users during video consultations, which hindered the access of elderly individuals who did not have the skills to deal with information technologies.

I believe that the main difficulty refers to the use of the platform. The service was new in the city, so we were all adapting and had many problems during the process with the telephone system operating the service. (S21) At first, I had some difficulty accessing the system, but later it became easier. Regarding the patients, they often had to receive some guidance via video calls with the professionals. Some patients, especially the elderly, had difficulties accessing the website. There was this time when I was with an elderly lady who needed access to a video consultation with a physician. I recall that she tried approximately one hour to access the website while I guided hervia telephone. She was almost quitting when finally, she managed to access the website, and she was very thankful. The main difficulties concerned problems with the telephone system when the landline calls dropped during consultations or the calls were not forwarded to the attendants. (S12)

Note that the use of the telehealth service revealed a need for investments in infrastructure, including efficient information standards and ICTs in health, to obtain interoperability. These investments are not restricted to financial resources; they also imply changing culture in the Brazilian context ${ }^{(14)}$.

Furthermore, it is worth noting that the rapid and growing development of services that use communication technologies in the health field requires these technologies to be assessed in terms of usability. This term refers to the users' acceptance, contributing to their effective implementation. To achieve the usability of a system, it has to be usable; that is, users need to understand and memorize it easily, having a pleasant and satisfactory experience, without obstacles and a minimum of errors ${ }^{(19)}$. 
Another weakness of the service is that the telehealth service has some restrictions; people have difficulties accessing this type of technology. This weakness is addressed in the literature, showing that it is necessary to re-think the strategies used to access a telehealth service's information and virtual resources because more straightforward access facilitates the consultations of elderly individuals composing the risk group for COVID-19.

Thus, strategies such as using image processing applications accessed via mobile are suggested, such as Skype and video calls, which require users to type only one key, to remedy the difficulties faced by people with decreased capacity or limitations when using this technology ${ }^{(20)}$. Additionally, a growing number of applications are being developed to support users and meet the greater demand due to the risk of infection by the COVID-19. Among these is the Coronavirus-SUS application from the Ministry of Health, which is intended to inform the population of the COVID-19 symptoms and how to prevent it, also enabling users to check whether their symptoms are compatible with the disease and referring them to the nearest primary healthcare unit based on the user's location(21).

Another essential weakness reported by the participants refers to fragmentation between health services. For example, the users would provide personal and clinical information, which was registered in the service platform, but then had to provide all the information again when referred to faceto-face service. Additionally, in some cases, the service was discontinued in the face-to-face service because the telehealth service provided conflicting information to the users and the primary healthcare unit.

Undoubtedly, the service was relevant in the care provided to the population to the extent that it clarified the users' doubts and supported their demands amidst the pandemic. On the other hand, as an intern, I saw the failures of the telehealth service considering that the service was not integrated into the primary healthcare network and there were many problems within the system, hindering quality service. (S8)

Because it's a new service, it presented failures and was not interconnected with the rest of the network, so there was conflicting information. (S15)

Therefore, the students emphasized the need to interconnect the services, especially in a pandemic situation when remote communication is established between users and health services. Therefore, using technologies to interconnect the units would prevent the loss of information, facilitating the nursing team's work.
Even though the fragmentation of health services is a weakness widely discussed in the Brazilian health system, remote consultations based on protocols were effective during the pandemic, mainly to preserve and direct users within the health system. However, discontinuity of care was also reported in other studies as a weakness of the service. Thus, health services need to be integrated with the remaining health networks via open communication channels to ensure more efficient and safer services ${ }^{(22)}$. Likewise, this integration in the COVID-19 pandemic context would favor the referral of patients, ensuring they were less exposed to the virus and preventing overloading the remaining components of the network.

Also, considering that the service is performed remotely via telephone, the students highlighted that not being able to assess patients physically was a weakness, considering that the skills needed to perform clinical assessments remotely were not explored during academic training, which demanded the students to pay greater attention to the signs and symptoms reported by the patients to make adequate referrals.

The main weakness lies in the difficulty of assessing a patient remotely, a subject not widely discussed during academic training. (S19)

It is extremely difficult to assess a patient via a telephone call and in a matter of minutes. It was challenging in the beginning, but it became easier over time as I acquired more experience. (S28)

The potentialities reported by the students included the importance of the telehealth service for the community, providing a service that comprises the reception of patients, clinical assessment, guidance, referral, prevention, and health education without the need for users to leave their homes and expose themselves in a face-to-face service, helping to decrease the overload of services.

I believe that the main potentiality is that it is a system through which patients can clarify and report their doubts, be assessed, and receive guidance without leaving their homes and being exposed to the virus. (S14)

Timely service, lower demand on hospitals, less exposure of people to the virus, decreased circulation of people. (S26)

Various studies report that the telehealth service is a decisive factor in improving emergency responses in times such as the COVID-19 pandemic ${ }^{(14,23)}$. In this context, the telehealth service enables health workers to provide care remotely, screen patients, provide information, demystify 
misconceptions, and even help to diagnose diseases. Therefore, the telehealth service is a remote health service essential to manage infectious diseases such as the COVID-19, promoting social distancing, decreasing the demand for face-to-face health services, and facilitating the access of patients and professionals to health services ${ }^{(23)}$.

Regarding the telehealth service's potentialities, the participants noted that it is a nursing setting that is currently unexplored during the undergraduate nursing program, and for this reason, the experience was even more challenging. Furthermore, the participants noted the service's potential to be expanded and meet others of the population's health needs, considering its capacity to hold many calls.

Because it is a service with which we have no contact during the undergraduate program, the experience was enriching both from a professional point of view and because you acquire a new perspective of the importance of having a service that provides education and promotes health prevention among the community, so people don't need to leave their homes to obtain the necessary information. (S14)

It's an innovative service that should be expanded to other fields. For instance, for patients who cannot commute to a unit and would be able to solve their problems virtually. (S10)

In addition to global emergencies, the telehealth service can be used to meet other health needs, such as continuously monitoring patients with chronic diseases and decreasing the number of face-to-face clinical consultations while providing guidance and ensuring safe care. Therefore, telehealth platforms efficiently manage the challenges imposed on health systems, as they alleviate overcrowding of hospitals and promote high-quality service ${ }^{(24)}$.

\section{Knowledge, skills and competencies developed in the telehealth service}

The following aspects were highlighted regarding the knowledge, skills, and competencies the students developed in the telehealth service: clinical reasoning, the use of technology, communication skills, teamwork with the multi-professional team, and decision-making. Regarding clinical reasoning, the students reported it was challenging to relate the users' reports with knowledge concerning the COVID-19 symptoms, considering it is a novel virus, while adapting to a remote service with which they had no previous experience.
Clinical reasoning was critical because even without physical assessment, it made me think about what had been reported and relate it to the COVID-19 symptoms, which, even though it is a disease under study, presents already known complications. (S26)

Much of the knowledge related to the telehealth service and the COVID-19 was acquired during the work, considering it is a modality never experienced before. However, clinical reasoning acquired during college was vital to perform the work. (S6)

Clinical practice implies nurses using clinical reasoning skills, which comprise cognitive processes and strategies used to identify a patient's actual or potential problem based on the data available, and make good decisions, regardless of the clinical setting. However, implement clinical reasoning in a telehealth service may be challenging and demand a different approach, considering that care is provided remotely and is based on information and communication technologies. Hence, the literature shows that factors such as the system's continuous flow of clinical data, the possibility to maintain regular contact with patients, and shared decision-making with patients, favor the reasoning processes of nurses working in telehealth services ${ }^{(25)}$.

Even though the students emphasized the knowledge and clinical reasoning skills developed during the undergraduate program, they also noted a need to explore the clinical assessment of patients remotely during academic training. Additionally, given the impossibility to perform the physical assessment and aiming to perform an adequate clinical assessment, the students reported the use of strategies such as paying attention to the patients' voice tone, how long they needed to answer questions, and whether they presented any signs of fatigue, or cough, for instance.

I believe that the development of clinical reasoning over the undergraduate program was decisive because it enabled me identify the patients' complaints and find potential solutions for their problems, considering the particularities of each individual (S17)

Sharp clinical reasoning to associate the symptoms reported by the patients to the appropriate pathologies. Anamnesis, because even though we could not see the patient and perform a good physical assessment, we could ask questions, listen to their breath through the call, and by the way they were speaking, we could have an idea of the severity. And the screening... unfortunately, we didn't have any experience with a telehealth service over the program, never had any 
course about it, so it was something completely new and unexpected. (S28)

When I talked to the patient, I'd pay attention to his breath, whether he was coughing, showed signs of fatigue when talking, and l'd asked about the symptoms and asked him to verify his temperature while we were talking. (S22)

For this service to be strengthened and used in the routine of healthcare services, telehealth services need to be included in the curricula of undergraduate and graduate health programs. Thus, future health professionals need to be trained to adopt this service as part of the current care provided to patients. Additionally, its increased use in the routine of services enables this technology to be a more sustainable model of care than a mere complementary health service ${ }^{(23)}$.

The students mentioned that establishing effective communication with patients is an essential ability to develop clinical reasoning, contributing to adequate assessments and clinical conduct. Therefore, they highlighted the use of technology to facilitate learning and communication between users and workers and among workers.

The knowledge concerning the skills demanded by a nurse, such as good communication (with the team, patients, and health service), know how to apply theoretical knowledge when talking to patients, be sharp when assisting the patients, among others. (S12)

Being able to interpret what the patient reported concerning signs and symptoms without seeing the patient, and based on this assessment, ask other questions that enabled to more completely visualize the patient's clinical condition, performing the best conduct as possible. It was a challenging experience, having to relate theoretical and practical knowledge, only dialoguing with patients remotely, without seeing them or performing a physical assessment. (S29)

It was really smooth, easy to talk with other professionals, and try my best to make adequate referrals. The technology facilitated this approximation with the other team members. (S31)

Appropriate communication influences the behavior of students and/or nurses during their work in the telehealth service, considering that efficient communication is vital to the quality of the health care provided to patients. Therefore, clear communication helps students and/or nurses to minimize conduct errors, ensure patient safety, and enable care using communication technologies within the health field. Additionally, video nursing consultations can further favor communication, strengthening the care provided by nurses working in telehealth services ${ }^{(25)}$.

The participants emphasized the development of communication skills and competencies considering their active participation in providing orientations regarding the most common symptoms, the signs that could appear over time and would indicate a more severe condition, preventive measures to implement in the case an individual had had contact with a confirmed case or not, clarifying doubts, reassuring patients, and contributing to their protection, prevention, diagnosis, and treatment.

Here, I could apply all my knowledge to benefit the patient, orienting, talking, and clarifying their doubts. Sometimes, also reassuring patients when they manifested fear or anxiety. (S16)

This part I found very rewarding because I was able to teach health education well, transmit, and orient the patients so they could protect themselves and the community in general. (S14)

The orientations were usually related to the ways COVID-19 is prevented or disseminated. Personally, I never assisted a patient who was not suspected of COVID. So, it was necessary much study and updated information to provide the correct guidance. (S28)

Communication is a potential aspect of the telehealth service concerning the dissemination and clarification of the patients' doubts. Furthermore, considering the COVID-19 pandemic, providing remote guidance to the users is an important mechanism to decrease the spread of the virus, referring users to the proper level of care, protecting patients, health workers, and the community from being exposed to the infection, and avoiding overloading the health system ${ }^{(23)}$.

Finally, regarding the work of the multi-professional team, the students reported it was an enriching and realistic experience, which allowed them to exchange knowledge and discuss clinical cases and their respective referrals. Likewise, regarding the development of decision-making skills and competencies, the students noted that they became autonomous to refer cases based on clinical reasoning and by constantly seeking knowledge and discussing with the multi-professional team.

Working with the multi-professional team was a very productive experience because knowledge is exchanged daily by discussing cases and potential solutions. Over time, 
after assisting cases and discussing with the multi-professional team, I became more autonomous to make decisions, so it was an excellent experience for those who sought to improve. (S19)

I believe that clinical knowledge and diagnosing were essential. However, I believe that issues concerning problem-solving capacity and critical reasoning were the main ones. (S21)

A study addressing nursing students attending the last semester of the program reports that after the students participated in telehealth simulations - intended to allow the students to learn and practice intra- and inter-professional collaboration -, the technology enabled students to learn the competencies essential for providing safe and efficient care, including improved clinical reasoning, real-world practice, communication, and application to the clinical practice ${ }^{(26)}$.

\section{finAl CONSIDERATIONS}

This study presents the experiences of nursing students with a telehealth service to fight the COVID-19. The students perceived the facilities, weaknesses, and potentialities of the telehealth service. They highlighted it was a setting previously unexplored in the academic training of nurses, showing a need for improving the educational process in the nursing field to consolidate the telehealth service as a work setting within the profession. Regarding knowledge, skills, and competencies developed in the service, the students mentioned that communication was an essential ally in the delivery of safe and quality service.

This study's limitations include the fact that it was conducted in a single telehealth service and included only a group of students, which are characteristics relevant to the results. Nevertheless, these results are expected to encourage further research addressing telehealth services in the health field to promote their use in care practice.

\section{REFERENCES}

1. Ministério da Saúde (BR). Secretaria de Vigilância em Saúde. Guia de vigilância epidemiológica emergência de saúde pública de importância nacional pela doença pelo Coronavirus 2020 [Internet]. Brasília (DF): Ministério da Saúde;2020 [cited 2020 Nov 14]. Available from: https://bvsms.saude.gov.br/bvs/publicacoes/ guia_vigilancia_epidemiologica_emergencia_saude_publica_importancia_ nacional_doenca_coranvirus.pdf

2. Organização Pan-Americana de Saúde. Folha informativa sobre COVID-19 [Internet]. 2020 [cited 2020 Nov 14]. Available from: https://www.paho.org/bra/index. php?option=com_content\&view=article\&id=6101:covid $19 \& \mid$ temid $=875$
3. Kraemer MUG, Yang CH, Gutierrez B, Wu CH, Klein B, Pigott DM, et al. The effect of human mobility and control measures on the COVID-19 epidemic in China. Science. 2020;368(6490):493-7. doi: https://doi.org/10.1126/science.abb4218

4. Paloski GR, Barlem JGT, Brum AN, Barlem ELD, Rocha LP, Castanheira IS. Telehealth contributions to fighting COVID-19. Esc Anna Nery. 2020;24(spe):e20200287. doi: https://doi.org/10.1590/2177-9465-EAN-2020-0287

5. World Health Organization [Internet]. Geneva:WH0; 2021 [cited 2020 Nov 14]. Coronavirus disease (COVID-19) pandemic; [about 5 screens]. Available from: https://www.who.int/emergencies/diseases/novel-coronavirus-2019

6. Hollander JE, Carr BG. Virtually perfect? telemedicine for Covid-19. N Engl J Med. 2020;382:1679-81. doi: https://doi.org/10.1056/NEJMp2003539

7. Universidade de São Paulo [Internet]. São Paulo: USP; 2020 [cited 2020 Nov 14]. Disciplina de telemedicina da FMUSP cria vídeo em 3D sobre etiqueta respiratória durante a pandemia da Covid-19; [cerca de 3 telas]. Available from: https://www. fm.usp.br/fmusp/noticias/disciplina-de-telemedicina-da-fmusp-cria-video-em3d-sobre-etiqueta-respiratoria-durante-a-pandemia-da-covid-19

8. When CL. Telemedicina e telessaúde [Internet]. homem virtual impresso em 3D: novas perspectivas para a educação em saúde no Brasil; 2020 [cited 2020 Nov 14]. Available from: http://chaowen.med.br/reflexoes-e-tendencias/ homem-virtual-impresso-em-3d-novas-perspectivas-para-a-educacaoem-saude-no-brasil/

9. Brasil. Lei n013.989, de 15 de abril de 2020. Dispõe sobre 0 uso da telemedicina durante a crise causada pelo coronavírus (SARS-CoV-2). Diário Oficial União. 2020 abr 16 [cited 2020 Nov 14];172(73 Seção 1):1. Available from: https://pesquisa.in.gov.br/imprensa/jsp/visualiza/index. jsp?data $=16 / 04 / 2020 \& j$ ornal $=515 \&$ pagina $=1 \&$ totalArquivos $=95$

10. Conselho Federal de Enfermagem (BR). Resolução n.634, de 26 de março de 2020. Autoriza e normatiza, "ad referendum" do Plenário do Cofen, a teleconsulta de enfermagem como forma de combate à pandemia provocada pelo novo coronavírus (Sars-Cov-2), mediante consultas, esclarecimentos, encaminhamentos e orientaçôes com uso de meios tecnológicos, e dá outras providências. Diário Oficial União. 2020 mar 27 [cited 2020 May 26];172(60 Seção 1):117. Available from: https://pesquisa.in.gov.br/imprensa/spp/visualiza/index. jsp?data $=27 / 03 / 2020 \&$ jornal $=515 \&$ pagina $=117$

11. Moraes R, Galiazzi MC. Análise textual discursiva. 2. ed. Ijuí: Unijuŕ; 2013.

12. Prefeitura de Porto Alegre. Secretaria de Saúde. Boletim COVID-19 no 198/2020 [Internet]. 2020 [cited 2020 May 26]. Available from: http://lproweb.procempa. com.br/pmpa/prefpoa/sms/usu_doc/2020_10_30_boletim_covid_sms_198. pdf

13. Maeyama MA, Calvo MCM. A integração do telessaúde nas centrais de regulação: a teleconsultoria como mediadora entre a atenção básica e a atenção especializada. Rev Bras Educ Med. 2018;42(2):63-72. doi: http://doi. org/10.1590/1981-52712015v42n2rb20170125

14. Caetano R, Silva AB, Guedes ACCM, Paiva CCN, Ribeiro GR, Santos DL etal. Challenges and opportunities for telehealth during the COVID-19 pandemic: ideas on spaces and initiatives in the Brazilian context. Cad Saúde Pública. 2020; 36(5):e00088920. doi: https://doi.org/10.1590/0102-311X00088920

15. Soares SSS, Carvalho EC, Varella TCMML, Adrade KBS, Souza TDO, Souza NVDO. Brazilian nursing in the fight against the infodemic during the covid-19 pandemic. Cogitare Enferm. 2020;25:e74676. doi: http://doi.org/10.5380/ ce.v25i0.74676

16. Jia Y, Chen O, Xiao Z, Xiao J, Bian J, Jia H. Nurses' ethical challenges caring for people with COVID-19: a qualitative study. Nurs Ethics. 2021;28(1):33-45. doi: https://doi.org/10.1177/0969733020944453 
17. Silva TL,Tomaschewski-Barlem JG, Barlem ELD, Brum RG, Neutzling BRS, Lourenção LG.Nursing undergraduates' understanding of health care networks. Rev Enferm UERJ. 2020;28:e45918. doi: https://doi.org/10.12957/ reuerj.2020.45918

18. Ministério da Saúde (BR). Secretaria de Ciência, Tecnologia e Insumos Estratégicos Departamento de Ciência e Tecnologia. Guia metodológico para programas e serviços em telessaúde. Brasília (DF): Ministério da Saúde; 2019. [cited 2020 May 26]. Available from: http://www.ans.gov.br/images/MS-telessaudemanual_2019.pdf

19. Klaassen B, van Beijnum BJF, Hermens HJ. Usability in telemedicine systems: a literature survey. Int J Med Inform. 2016;93:57-69. doi: https://doi.org/10.1016/j. ijmedinf.2016.06.004

20. Banskota S, Healy M, Golberg EM. 15 smartphone apps for older adults to use while in isolation during the COVID-19 pandemic. West J Emerg Med. 2020;21(3):514525. doi: https://doi.org/10.5811/westjem.2020.4.47372

21. Ministério da Saúde (BR) [Internet]. Brasília (DF): Ministério da Saúde; 2020 [cited 2020 May 26]. Ministério da Saúde já atendeu 471,6 mil pessoas à distância; [cerca de 2 telas]. Available from: https://www.gov.br/saude/pt-br/assuntos/noticias/ ministerio-da-saude-ja-atendeu-471-6-mil-pessoas-a-distancia
22. Medina MG, Giovanella L, Bousquat A, Mendonça MHM, Aquino R, Comitê Gestor da Rede de Pesquisa em Atenção Primária à Saúde da Abrasco. Primary healthcare in times of COVID-19: what to do? Cad Saúde Pública. 2020;36(8):e00149720. doi: https://doi.org/10.1590/0102-311x00149720

23. Smith AC, Thomas E, Snoswell CL, Haydon H, Mehrotra A, Clemensen J. et al. Telehealth for global emergencies: implications for coronavirus disease 2019 (COVID-19). J Telemed Telecare. 2020;26(5):309-13. doi: https://doi. org/10.1177/1357633X20916567

24. Rockwell KL, Gilroy AS. Incorporating telemedicine as part of COVID-19 outbreak response systems [commentary]. Am J Manag Care. 2020;26(4):147-8. doi: https://doi.org/10.37765/ajmc.2020.42784

25. Barken TL, Thygesen E, Söderhamn U. Advancing beyond the system: telemedicine nurses' clinical reasoning using a computerised decision support system for patients with COPD - an ethnographic study. BMC Med Inform Decis Mak. 2017;17:181. doi: https://doi.org/10.1186/s12911-017-0573-7

26. Powers K, Neustrup W, Thomas C, Saine A, Sossoman LB, Ferrante-Fusilli FA, et al. Baccalaureate nursing students' experiences with multi-patient, standardized patient simulations using telehealth to collaborate. J Prof Nurs. 2020;36(5):292300. doi: https://doi.org/10.1016/j.profnurs.2020.03.013 


\section{- Authorship contribution:}

Luana Daiane Guimarães Lima: Conceptualization, Data curation, Investigation, Methodology, Resources, Writing - original draft. Jamila Geri Tomaschewski-Barlem: Conceptualization, Data curation, Formal analysis, Project's administration, Methodology, Resources, Supervision, Writing - original draft - review and editing.

Gabriela do Rosário Paloski: Data curation,

Methodology, Writing - original draft, Writing - review and editing.

Edison Luiz Devos Barlem: Conceptualization, Formal analysis, Supervision, Writing - review, and editing. Laurelize Pereira Rocha: Formal analysis, Supervision, Writing - review, and editing. Janaína Sena Castanheira: Data curation, Formal analysis, Supervision, Writing - review, and editing.

The authors declare no conflict of interest.

\section{- Corresponding author:}

Gabriela do Rosário Paloski

E-mail: gabipaloski@outlook.com

Associate editor:

Rosana Maffacciolli

Editor-in-chief:

Maria da Graça Oliveira Crossetti 